\title{
THE GEOGRAPHY OF THE END CONSUMERS OF THE LOGISTIC PRODUCT FLOWS IN WESTERN UKRAINE
}

\author{
'Volodymyr GRYTSEVYCH, ${ }^{2}$ Mariana SENKIV \\ Ivan Franko National University of Lviv, Ukraine \\ 'gvsmg@ukr.net, ${ }^{2} m . s e n k i v @ I n u . e d u . u a$
}

\begin{abstract}
Consumption is the end stage of the logistic movement of the final products. The main end consumer of these flows are people (individuals and households). Therefore, human-geographical analysis, directed on the regional spatial population pattern, is important for optimization of logistic flows. In this paper, the population of the region is segmented by three important aspects: place of residence (urban or rural), sex (female, male), main age groups. The maximal amounts of consumers in the Western Ukraine is concentrated in Lviv region, while Chernivtsi region has minimal amount of consumers. Consumers from urban settlements dominate in Lviv, Khmelnytskyi and Volyn regions, while rural consumers prevail in all other regions. Generally, in Western region of Ukraine, rural consumers dominate over urban ones. The share of female consumers dominates over the share of male consumers in the Western Ukraine in whole and in all separately taken districts. Administrative districts, located along the Western Ukrainian borderland, have deviation from the average regional structure, specifically, a larger share of female population. On the contrary, deviation from the average regional structure in internal regions consists in a larger share of male population. Conserning the age structure, consumers of the working age dominate in Western region of Ukraine, and the younger working age customers prevail over the older working age consumers. Zakarpattya and northern part of Volyn have relatively larger share of younger working age customers, while Podolian areas are characterized by relatively larger share of older working age consumers.
\end{abstract}

Key words: region, administrative district, end consumer, population structure.

DOI: https://doi.org/10.17721/2413-7154/2017.77.25-32

UDC: 911.3

\section{ГЕОГРАФІЯ КІНЦЕВИХ СПОЖИВАЧІВ ЛОГІСТИЧНИХ ТОВАРНИХ ПОТОКІВ У ЗАХІДНОМУ РЕГІОНІ УКРАЇНИ}

\author{
'Володимир ГРИЦЕВИЧ, '²ар'яна СЕНЬКІВ \\ 'Львівський національний університет імені Івана Франка, Україна \\ 'gvsmg@ukr.net, ${ }^{2}$ m.senkiv@Inu.edu.ua
}

\begin{abstract}
Анотація: Кінцевою стадією руху логістичного потоку готової продукції $\epsilon$ споживання. Головним кінцевим споживачем цих потоків $\epsilon$ населення (окремі особи, а також домашні господарства). Тому важливим $\epsilon$ суспільногеографічний аналіз особливостей просторової диференціації населення регіону для планування оптимальних логістичних потоків. Населення регіону сегментоване за трьома важливими аспектами: місцем проживання (місто, село), статтю (жінки, чоловіки), головними віковими групами. Найбільша кількість споживачів в регіоні характерна для Львівської області, найменша - для Чернівецької. У структурі чисельності споживачів Львівської, Хмельницької і Волинської областей переважають споживачі міських поселень, в усіх інших областях переважають споживачі сільської місцевості. Загалом, у ЗРу частка споживачів сільської місцевості переважає над часткою споживачів міських поселень. У ЗРу загалом і в усіх окремо взятих районах частка споживачів-жінок є більшою, ніж частка споживачівчоловіків. Для адміністративних районів областей західноукраїнського прикордоння спостерігається відхилення від середньорегіональної структури в сторону більшої частки жінок. Водночас, для внутрішніх областей спостерігається відхилення від середньорегіональної структури в сторону більшої частки чоловіків. За віком у Зру переважають споживачі працездатного віку, а частка споживачів молодших за працездатний вік $\epsilon$ більшою, ніж частка споживачів старших за працездатний вік. Для адміністративних районів Закарпаття та півночі Волині характерне відхилення від середньорегіональної вікової структури в сторону більшої частки споживачів молодших працездатного віку. Райони Поділля характеризуються відхиленням від середньорегіональної вікової структури в сторону більшої частки споживачів старших працездатного віку.
\end{abstract}

Ключові слова: регіон, адміністративний район, кінцевий споживач, структура населення.

DOI: https://doi.org/10.17721/2413-7154/2017.77.25-32

UDC: 911.3

Постановка проблеми.

У логістичній системі регіону кінцевою стадією руху логістичного потоку готової продукції

(C) В. Грицевич, М. Сеньків є споживання. Головним споживачем логістичних потоків готової продукції $\epsilon$ населення (окремі особи, а також домашні господарства). Посередники, зокрема, організації гуртової і роздрібної торгівлі також оперують логістичними потоками готової 
продукції. Для ефективного планування логістичних потоків і відповідного сегментування ринку та розумної маркетингової політики потрібен детальний аналіз географії кінцевого споживання в досліджуваному регіоні. При цьому зрозуміло, що ця географія істотно залежить від співвідношення суспільно важливих груп населення, що істотно відрізняються за характером особистого споживання. Ми розглянемо три варіанти декомпозиції населення: за місцем проживання (місто, село), за статтю (жінки, чоловіки) та за трьома головними віковими групами з точки зору транспортної та розподільчої логістики.

Аналіз останніх публікацій.

Дослідження географії кінцевих споживачів товарів регіону у логістичному контексті $є$ новими

i мало розробленими в Україні. У публікації Грицевича В. С. [1] запропонована структура демогеографічних даних регіону, розроблені математичні моделі таксонів, розглянуте застосування інтелектуального аналізу даних до демографічних показників самоорганізації регіону на прикладі асоціативного аналізу. Окремим аспектам вивчення споживчого ринку в Україні присвячені праці Гродецької Т. М. [2], Сухаревської І. В. [7], Шевчук О. В. [16] та ін. Використання маркетингових технологій в збутовій діяльності переробних підприємств на продовольчому ринку досліджене в роботі Івасенко О. А. [3]. Аналіз основних регіональних особливостей формування та розвитку споживчого ринку регіону, а також чинники, які на них впливають, здійснено у статті Кондри О. Р. [4]. Методику застосування логістичного підходу до вдосконалення регіонального ринку споживчих товарів і послуг досліджено в статті Мигаленка О. І. [5]. Статистична інформація щодо людності адміністративних районів ЗРУ міститься у статистичних щорічниках областей [8-15].

Формулювання цілей статті.

Метою роботи є суспільно-географічний аналіз особливостей просторової диференціації населення Західного регіону України, як кінцевого споживача товарних логістичних потоків, за головними варіантами декомпозиції населення, що потрібно для науково обгрунтованої сегментації ринку товарів, логістичних товарних потоків і відповідної маркетингової політики суб'єктів транспортної та розподільчої логістичної діяльності.

Виклад основного матеріалу.

Кінцевими споживачами матеріальних і супутніх йому потоків у ЗРУ $\epsilon$ окремі особи i домашні господарства. Найбільша кількість споживачів в регіоні характерна для Львівської області, найменша - для Чернівецької. Міста регіону 3 найбільшою кількістю споживачів $є$ обласними центрами: Львів, Хмельницький, Чернівці, Рівне, ІваноФранківськ, Луцьк, Ужгород. Серед міст обласного значення регіону виділяються великою кількістю споживачів міста Кам'янець-Подільський, Дрогобич, Мукачеве, Ковель, Калуш, Коломия та ін. Розглянемо територіальну диференціацію трьох головних декомпозицій населення: урборуральну, статеву і вікову.
Територіальна диференціація кінцевих споживачів за урборуральною структурою.

Місце проживання людей має великий вплив на спеціалізацію товарних потоків, які вони споживають. Наприклад, жителі міст купляють практично всі продукти харчування, відносно менше товарів для будівництва, значну частку сучасної домашньої техніки. Навпаки, жителі сіл купляють більше засобів для сільськогосподарської діяльності, частину продуктів харчування виробляють для себе самі, ведуть власне житлове будівництво. Також частка витрат на купівлю промислових товарів, у тому числі одягу і взуття, в споживчих витратах набагато вища у сільського населення, ніж у міського.

Нехай $p_{k}^{i}$ і $p_{k}^{\tilde{n}}$ відповідно кількість міських і сільських жителів у $k$-му адміністративному районі регіону, $k=1, \ldots, K ; \quad K \quad-$ кількість адміністративних районів.

Обчислимо низку необхідних похідних величин:

$p_{k}=p_{k}^{i}+p_{k}^{\tilde{n}}-$ кількість населення $k$-го району;

$P^{i}=\sum_{k=1}^{K} p_{k}^{i}-$ кількість міських жителів регіону;

$P^{\tilde{n}}=\sum_{k=1}^{K} p_{k}^{\tilde{n}}-$ кількість сільських жителів регіону;

$P=P^{i}+P^{\tilde{n}}-$ загальна чисельність населення регіону;

$\mathrm{p}_{k}^{i}=\frac{p_{k}^{i}}{p_{k}}-$ частка міських жителів $k$-го району;

$\mathrm{p}_{k}^{\tilde{n}}=\frac{p_{k}^{\tilde{n}}}{p_{k}}-$ частка сільських жителів $k$-го району;

$\overline{\mathrm{p}}_{\text {регіону; }}^{i}=\frac{P^{i}}{P}-$ середня частка міських жителів $\overline{\mathrm{p}}_{\text {регіону. }}^{\tilde{n}}=\frac{P^{\tilde{n}}}{P}-$ середня частка сільських жителів

Далі обчислимо відносне перевищення чисельності сільських жителів над чисельністю міських жителів у кожному адміністративному районі за формулою:

$$
\frac{p_{k}^{\tilde{n}}-p_{k}^{i}}{p_{k}} \cdot 100 \%
$$

i картографічно покажемо це перевищення за допомогою картограми.

Для більш рельєфного картографічного відображення часток міських і сільських жителів за районами обчислимо їхні відхилення від відповідних середньорегіональних величин, тобто: 


$$
\left(\mathrm{p}_{k}^{i}-\overline{\mathrm{p}}^{i}\right) \text { i }\left(\mathrm{p}_{k}^{\tilde{n}}-\overline{\mathrm{p}}^{\mid \tilde{n}}\right)
$$

і зобразимо відхилення картографічно за допомогою стовпчикових діаграм. Зрозуміло, що серед відхилень будуть як додатні, так і від'ємні значення. Отримаємо картосхему (рис. 1).

У структурі чисельності споживачів Львівської, Хмельницької і Волинської областей переважають споживачі міських поселень, в усіх інших областях переважають споживачі сільської місцевості, для яких, як відомо, характерні менші доходи, а отже, нижчі рівні платоспроможності і споживання товарів. Загалом, у ЗРУ частка споживачів сільської місцевості переважає над часткою споживачів міських поселень, така ж тенденція стосується усіх районів, за виключенням міст (рис. 1). Найбільші в регіоні відхилення часток споживачів міських поселень і сільської місцевості від середньорегіональних значень мають райони: Герцаївський, Іршавський, Глибоцький, Путильський, Пустомитівський, Новоушицький та ін. Ці ж райони мають максимальне в регіоні відносне перевищення кількості сільського населення над кількістю міського населення.

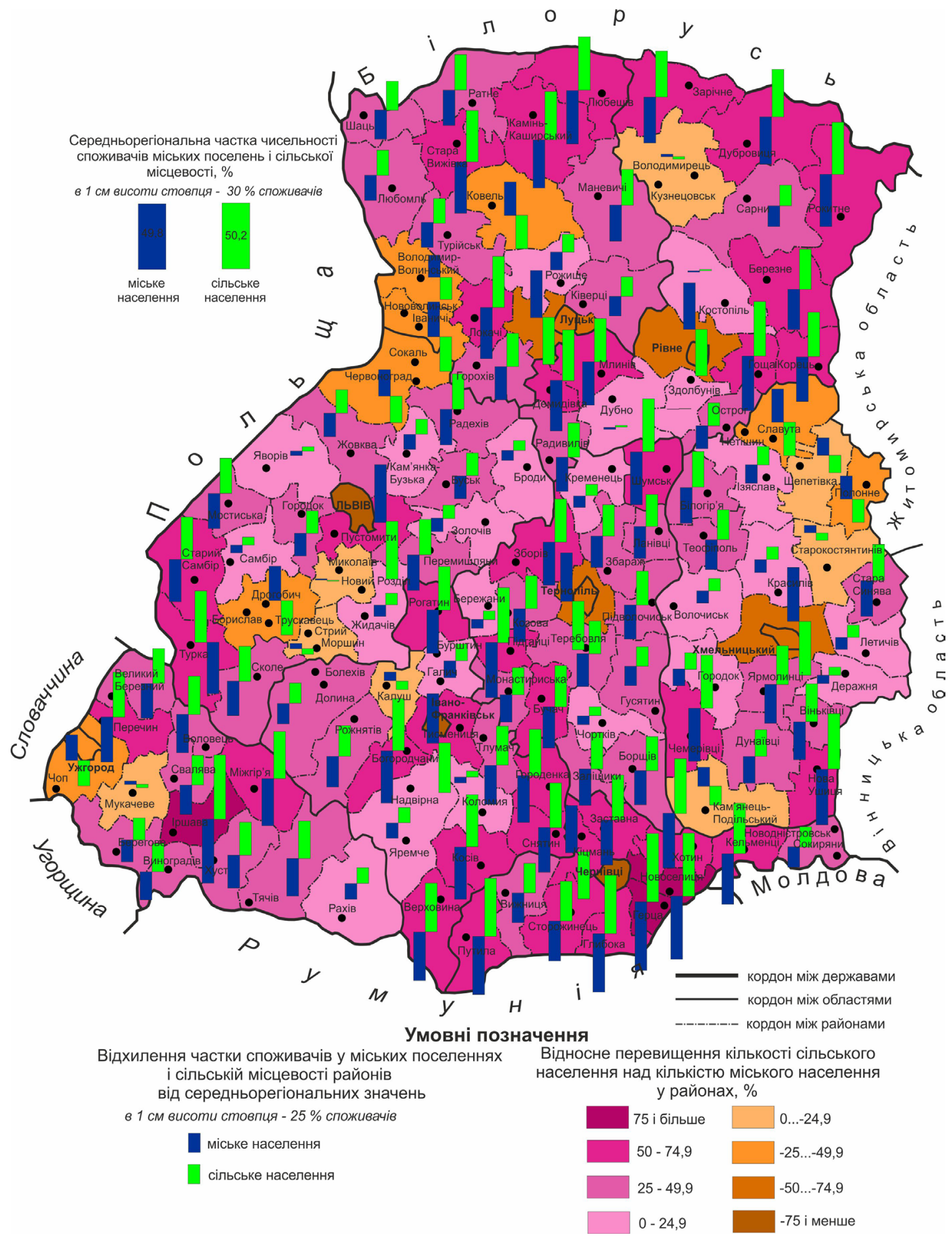

Рис. 1. Кінцеві споживачі ЗРУ за місцем проживання. 
Територіальна диференціація кінцевих споживачів за статевою структурою.

Статева структура населення також має велике значення у формуванні його споживчого попиту i відповідних логістичних товарних потоків. Жінки та чоловіки відрізняються за обсягом та характером попиту на одяг, взуття, інструменти для ручної роботи, транспортні засоби, ліки, друковані видання. Чоловіки більше, ніж жінки, споживають алкогольні і тютюнові вироби.

Нехай $p_{k}^{c e}$ і $p_{k}^{\div}$відповідно кількість жінок i чоловіків у $k$-му адміністративному районі регіону, $k=1, \ldots, K$.

Обчислимо низку необхідних похідних величин:

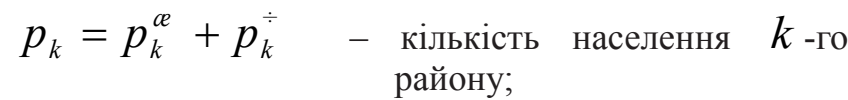

$P^{\alpha}=\sum_{k=1}^{K} p_{k}^{\infty}-$ кількість жінок у регіоні;

$P^{\div}=\sum_{k=1}^{K} p_{k}^{\div}-$кількість чоловіків у регіоні;

$P=P^{e}+P^{\div}-$загальна чисельність населення регіону;

$\mathrm{p}_{k}^{c}=\frac{p_{k}^{c}}{p_{k}}$ - частка жінок $k$-го району;

$\mathrm{p}_{k}^{\div}=\frac{p_{k}^{\div}}{p_{k}}-$ частка чоловіків $k$-го району;

$\overline{\mathrm{p}}^{\propto}=\frac{P^{\varkappa}}{P}-$ середня частка жінок у регіоні;

$\overline{\mathrm{p}} \div=\frac{P^{\div}}{P}-$ середня частка чоловіків у регіоні.

Далі обчислимо відносне перевищення чисельності чоловіків над чисельністю жінок у кожному адміністративному районі за формулою:

$$
\frac{p_{k}^{\div}-p_{k}^{c}}{p_{k}} \cdot 100 \%
$$

i картографічно покажемо це перевищення за допомогою картограми.

У зв'язку з тим, що частки жінок та чоловіків за районами відрізняються мало і тому їх безпосередньо незручно картографувати, обчислимо їхні відхилення від відповідних середньорегіональних величин, тобто:

$$
\left(\mathrm{p}_{k}^{a}-\overline{\mathrm{p}}^{a}\right)_{\mathrm{i}}\left(\mathrm{p}_{k}^{\div}-\overline{\mathrm{p}}^{\div}\right)
$$

і зобразимо відхилення картографічно за допомогою стовпчикових діаграм. Зрозуміло, що серед відхилень будуть як додатні, так і від'ємні значення. Отримаємо картосхему (рис. 2).

У ЗРУ загалом i в усіх окремо взятих районах частка споживачів-жінок $є$ більшою, ніж частка споживачів-чоловіків (рис. 2). Найбільше відхилення часток груп споживачів за статтю від середньорегіональних значень характерне для Чемеровецького (від’ємне - для чоловіків, додатне - для жінок), Турківського (додатне - для чоловіків, від'ємне - для жінок), Любешівського (додатне - для чоловіків, від'ємне - для жінок) та ін. Максимальні в регіоні значення відносного перевищення кількості жінок над кількістю чоловіків мають райони: Чемеровецький, Ярмолинецький, Віньковецький, Збаразький, Городоцький (Хмельницької обл.), Дунаєвецький, Луцький (включно 3 м. Луцьк), Чортківський, Волочиський, Полонський та ін.

територіальна диференціація кінцевих споживачів за віковою структурою.

Структура населення за головними віковими групами (молодші працездатного віку, працездатного віку, старші працездатного віку) також впливає на специфіку попиту на товари та їхні логістичні потоки. Ці групи відрізняються за характером попиту на одяг та взуття, молодші працездатного віку формують попит на ігри та шкільні товари, особи працездатного віку формують головний попит на різноманітні товари широкого асортименту, старші працездатного віку звужують попит відповідно до своїх уподобань. Наприклад, відомо, що члени молодої сім’ї без дітей витрачають багато грошей на одяг, меблі і побутову техніку; з появою дитини серед членів сім'ї зростає попит на такі товари, як дитяче харчування, вітаміни, іграшки, коляски, трохи пізніше - велосипеди, піаніно тощо; люди похилого віку часто купляють медичні препарати і медичні прилади.

Нехай $p_{k}^{\text {ï̈â }}, p_{k}^{\ddot{a}}$ і $p_{k}^{\tilde{n} \ddot{a} a}$ відповідно кількість осіб молодших працездатного віку, працездатного віку i старших працездатного віку в $k$-му адміністративному районі регіону, $k=1, \ldots, K$.

Обчислимо низку необхідних похідних величин:

$p_{k}=p_{k}^{i \ddot{a} \hat{a}}+p_{k}^{\ddot{a}}+p_{k}^{\tilde{n} \ddot{a} \hat{a}}-$ кількість населення $P^{i \text { ïâ }}=\sum_{k=1}^{K} p_{k}^{i i a ̂} \quad \begin{gathered}\text {-кількість осіб молодших } \\ \text { працездатного віку в регіоні; }\end{gathered}$

$P^{\ddot{a}}=\sum_{k=1}^{K} p_{k}^{\ddot{a}} \quad \begin{gathered}\text { кількість осіб працездатного } \\ \text { віку в регіоні; }\end{gathered}$

$P^{\tilde{n ̃ i a ̂}}=\sum_{k=1}^{K} p_{k}^{\tilde{n} i \hat{a}} \quad \begin{gathered}\text { кількість осіб старших } \\ \text { працездатного віку в регіоні; }\end{gathered}$

$P=P^{\dddot{i} a \hat{a}}+P^{\ddot{a}}+P^{\tilde{n} \ddot{a}}-$ загальна чисельність населення регіону;

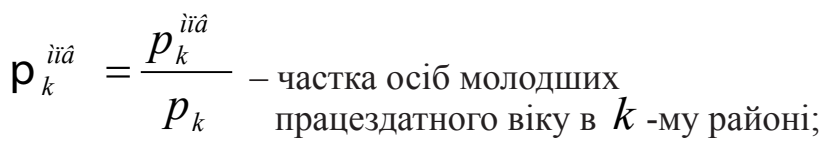


$\mathrm{p}_{k}^{\ddot{a}}=\frac{p_{k}^{\ddot{a}}}{p_{k}}-$ частка осіб працездатного віку в

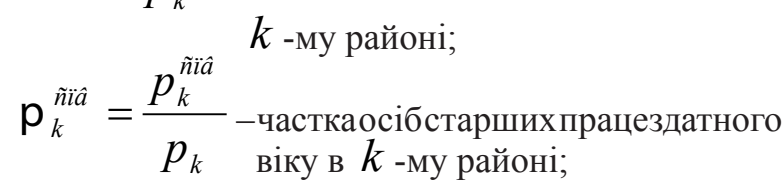

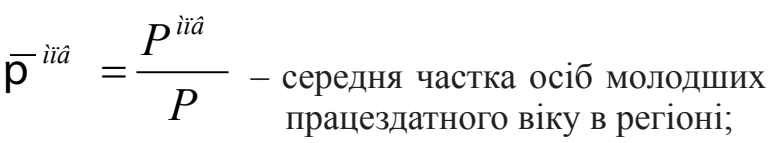

$\overline{\mathrm{p}}^{\ddot{a}}=\frac{P^{\ddot{a}}}{P}-\begin{gathered}\text { середня частка осіб працездатного } \\ \text { віку в регіоні; }\end{gathered}$ $\overline{\mathrm{p}}^{\tilde{n} \ddot{a}}=\frac{P^{\tilde{n} \ddot{a}}}{P}-\begin{gathered}\text { середня } \\ \text { працездатного віку в регіоні. }\end{gathered}$

$\mathrm{y}$ цьому випадку за допомогою картограми показуємо за адміністративними районами частку осіб працездатного віку $\mathbf{p}_{k}^{u}$.

Частки вікових груп за районами відрізняються мало i ix незручно безпосередньо картографувати, тому обчислимо їхні відхилення від

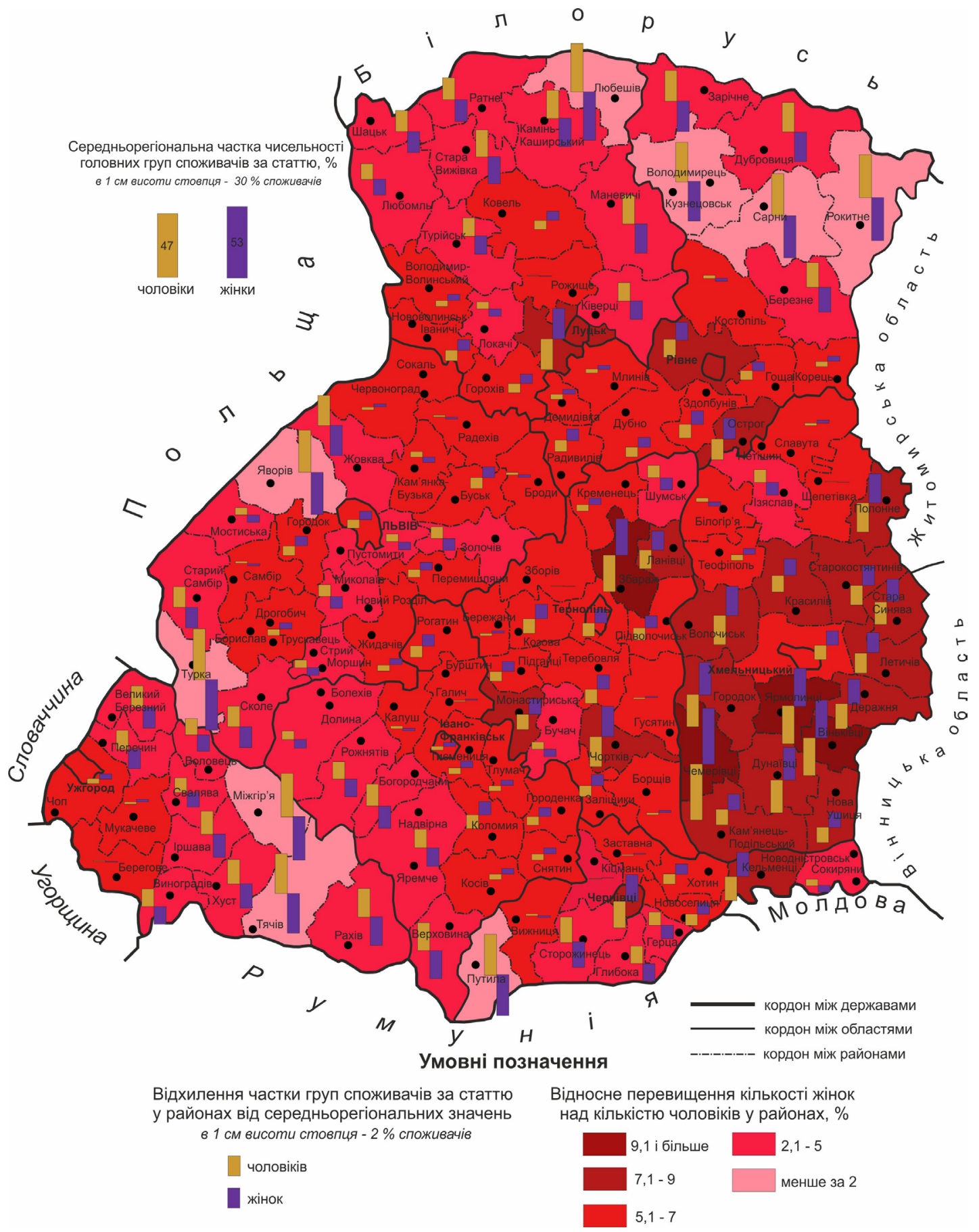

Рис. 2. Кінцеві споживачі ЗРУ за статтю. 
середньорегіональних величин, тобто:

$$
\left(\mathrm{p}_{k}^{i \ddot{a}}-\overline{\mathrm{p}}^{i \ddot{a} a}\right),\left(\mathrm{p}_{k}^{\ddot{a}}-\overline{\mathrm{p}}^{\ddot{a}}\right) \text { i }\left(\mathrm{p}_{k}^{\tilde{n} i \hat{a}}-\overline{\mathrm{p}}^{\tilde{n} \ddot{a} \hat{a}}\right)
$$

і зобразимо відхилення картографічно за допомогою стовпчикових діаграм. Зрозуміло, що серед відхилень будуть як додатні, так і від'ємні значення. Отримаємо картосхему (рис. 3).

За віком у ЗРУ переважають споживачі працездатного віку, а частка споживачів молодших за працездатний вік є більшою, ніж частка споживачів старших за працездатний вік (рис. 3). Особливості купівельної поведінки людей різного віку є різними.
Важливим фактором споживчої спроможності населення $€$ дохід. Середня заробітна плата в областях ЗРУ за грудень 2013 року становила 2938 грн, що на 681 грн менше, ніж в середньому по Україні за цей місяць, і на 1720 грн більше, ніж прожитковий мінімум для працездатних осіб у грудні 2013 року. Максимальні значення середньої зарплати за грудень 2013 року у регіоні були характерні для Рівненської, Хмельницької та Львівської областей. Абсолютним лідером за кількістю домогосподарств у регіоні $\epsilon$ Львівська область, найменше їх у Чернівецькій області. У структурі сукупних ресурсів домогосподарств областей регіону переважають

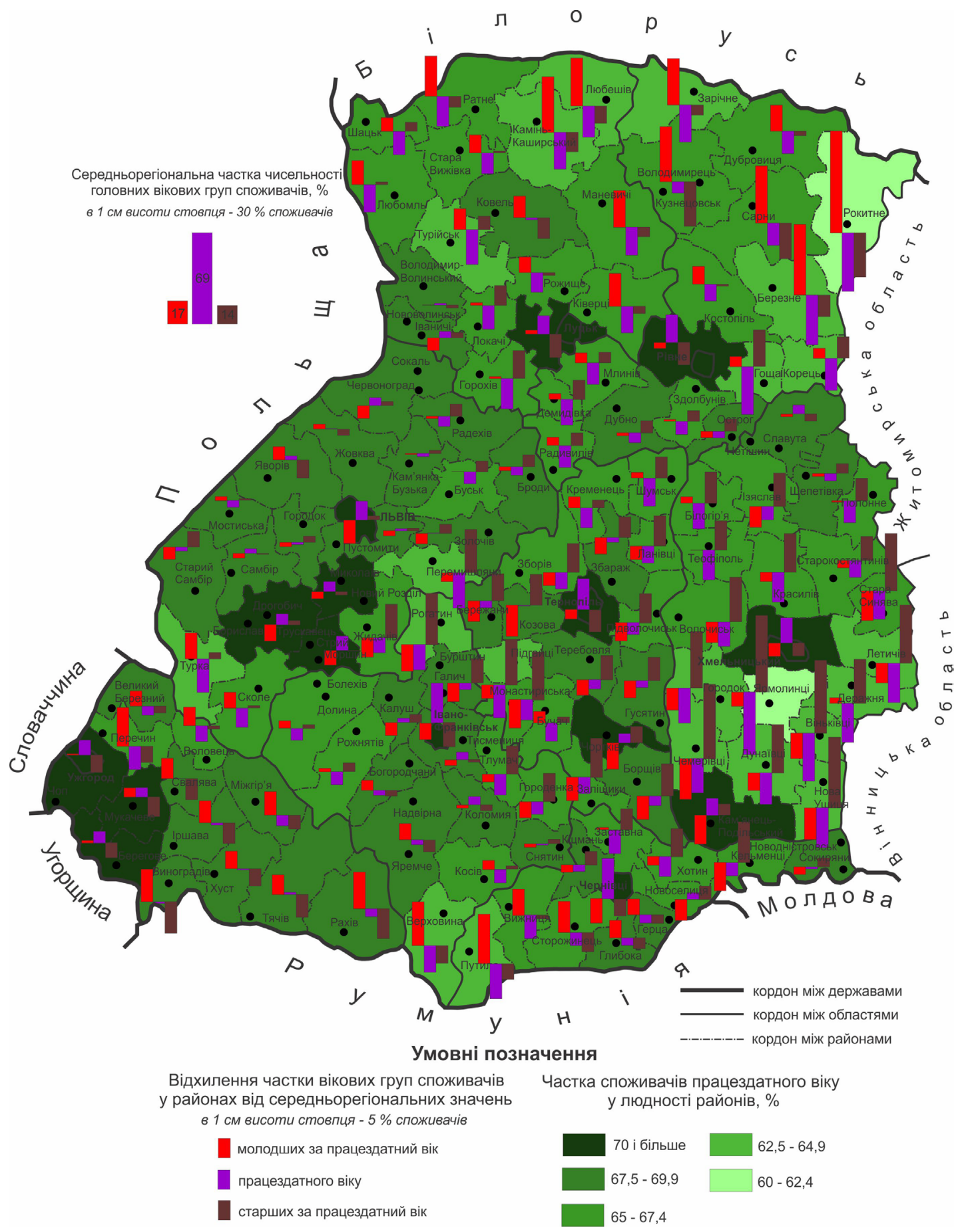

Рис. 3. Кінцеві споживачі Зру за віком. 
грошові доходи, зокрема, оплата праці, а також пенсії, стипендії, соціальні допомоги, надані готівкою. У структурі сукупних ресурсів домогосподарств Закарпатської, Чернівецької та Івано-Франківської областей значний відсоток припадає на доходи від підприємницької діяльності та самозайнятості. У структурі розподілу населення за рівнем середньодушових еквівалентних загальних доходів у місяць в областях регіону переважають частки 3 показниками 1560, 1-1920 грн і 1200,1-1560 грн.

В усіх областях регіону у структурі сукупних витрат домогосподарств переважають витрати на продукти харчування та безалкогольні напої, а також витрати на непродовольчі товари і послуги (найбільше-одяг і взуття; житло, вода, електроенергія, газ та інші види палива). Серед продуктів харчування у домогосподарствах найбільше споживають молоко i молочні продукти, а також яйця. В усіх областях регіону найбільша кількість домогосподарств має такі товари тривалого користування: кольорові телевізори, холодильники, мобільні телефони, пральні машини, електропилососи та ін., найменша кількість господарств володіє кондиціонерами, мотоциклами та сноумобілями [6].

Висновки. На території Західного регіону України в більшості адміністративних одиниць переважає сільське населення i лише в окремих високоурбанізованих ареалах спостерігається переважання міського населення, що разом із фактом кращого транспортного забезпечення урбанізованих ареалів є підставою для оптимальних логістичних рішень.

У ЗРУ різниця між статевою структурою різних районів на загал $є$ невеликою, однак вона існує i можна сказати, що для адміністративних районів областей західноукраїнського прикордоння спостерігається відхилення від середньорегіональної структури в сторону більшої частки жінок. Водночас, для внутрішніх областей (а це Поділля) спостерігається відхилення від середньорегіональної структури в сторону більшої частки чоловіків. Тобто маємо хорошу географічну закономірність, яку можна врахувати при плануванні логістичних потоків.

Аналогічно є підстави для оптимізації логістичних потоків, виходячи з вікової структури населення. Для адміністративних районів Закарпаття та півночі Волині характерне відхилення від середньорегіональної вікової структури в сторону більшої частки осіб молодших працездатного віку. Райони Поділля характеризуються відхиленням від середньорегіональної вікової структури в сторону більшої частки осіб старших працездатного віку.

\section{References:}

1. Gricevič V. S. Metodičnì osnovi vivčennâ demografičnoï samoorganizaciï regìonu v svitlì ìntelektual'nogo analizu danih [Methodical bases of studying regional demographic self-organization in the context of the intellectual data analysis]. In: Regìonal'nì problemi Ukraïni: geografičnij analìz ta pošuk šlâhìv virì̌ennâ [Regional problems of Ukraine: geographical analysis and searching for solutions], Kherson, 2011, pp. 88-96. (In Ukrainian).

2. Grodec'ka T. M. Transformaciâ spoživčogo rinku ta jogo regulûvannâ v perehidnij ekonomicì. [Transformation of consumer market and his regulation in transitional economy]. Author's abstract from PhD thesis. Kharkiv, 2002, 16 p. (In Ukrainian).

3. İvasenko O. A. Marketing zbutovoï diâl'nostì pererobnih pidpriêmstv na prodovol'čomu rinku. [Marketing of sale activity of processing enterprises on the food market]. Author's abstract from PhD thesis. Donetsk, 2009,20 p. (In Ukrainian).

4. Kondra O. R. Regional'nì osoblivosti formuvannâ ta rozvitku spoživčogo rinku regionu. [Regional consumer market: spatial patterns and development]. Ekonomìcnì nauki. Cerîâ: Oblìk ì fìnansi [Economic sciences. Series: Accounting \& Finance]. Lutsk, 2013, pp. 338-344.

5. Migalenko O. I. Logističnij pidhìd vdoskonalennâ regìonal'nogo spoživčogo rinku [Logistic approach to improve regional consumer market]. Teoretičnì ì praktičnì aspekti ekonomiki ta ìntelektual'noï vlasnostì [Theoretical and practical aspects of economics and intellectual property]. Mariupol, 2013, pp. 318-322. (In Ukrainian).

6. Official portal of the State Statistics Service of Ukraine. Access mode: http://ukrstat.gov.ua

7. Suharevs'ka I. V. Spoživčij rinok v sučasnih umovah. [Consumer market in modern conditions]. Author's abstract from PhD thesis. Donetsk, 2009, 20 p. (In Ukrainian).

8. Statističnij ŝoričnik "Volin' 2014". [Statistical yearbook "Volyn in 2014"]. Lutsk, 2015, 560 p. (In Ukrainian).

9. Statističnij ŝoričnik “Zakarpattâ 2014”. [Statistical yearbook “Zakarpattia in 2014”]. Uzhhorod, 2015,550 p. (In Ukrainian).

10. Statističnij ŝorìcnik İvano-Frankìvs'koï oblastì za 2014. [Statistical yearbook of Ivano-Frankivsk region in 2014]. Ivano-Frankìvsk, 2015, 534 p. (In Ukrainian).

11. Statističnij ŝoričnik L'vìvs'koï oblastì za 2014. Častina 1. [Statistical yearbook of Lviv region in 2014. Part 1]. Lviv, 2015, 370 p. (In Ukrainian).

12. Statističnij ŝorì̌nik Rìvnens'koï oblastì za 2014. [Statistical yearbook of Rivne region in 2014]. Rìvne, 2015 p, 480. (In Ukrainian).

13. Statističnij ŝorì̌nik Ternopil's'koï oblastì za 2014. [Statistical yearbook of Ternopil region in 2014]. Ternopil, 2015, 470 p. (In Ukrainian). 
14. Statističnij soroì̌nik Hmel'nic'koï oblastì za 2014. [Statistical yearbook of Khmelnytskyy region in 2014]. Khmelnytskyi, 2015, p. 426. (In Ukrainian).

15. Statističnij ŝorì̌nik Černìvec'koï oblastì za 2014. [Statistical yearbook of Chernivtsi region in 2014]. Chernivtsi, 2015, p. 604. (In Ukrainian).

16. Ševčuk O. V. Rozvitok spoživčogo rinku v transformacìjnij ekonomicì. [Development of consumer market in conditions of transformational economy]. Author's abstract from PhD thesis. Kyiv, 2011, 21 p. (In Ukrainian). 